\title{
The Transition of Interactional Patterns and Cellphone Usage Between Generations in the Belitung Community: A Year Before the COVID-19 Pandemic Mei Ie ${ }^{1.2^{*}}$ Anny Valentina ${ }^{1.3}$ Sri Tiatri ${ }^{1.4}$ Jap Tji Beng ${ }^{1.5}$
}

\author{
${ }^{1}$ Pusat Studi Budaya Tionghoa, Universitas Tarumanagara, Jakarta \\ ${ }^{2}$ Faculty of Economics and Business, Universitas Tarumanagara, Jakarta \\ ${ }^{3}$ Faculty of Art and Design, Universitas Tarumanagara, Jakarta \\ ${ }^{4}$ Faculty of Psychology, Universitas Tarumanagara, Jakarta \\ ${ }^{5}$ Faculty of Information Technology, Universitas Tarumanagara, Jakarta \\ *Corresponding author. Email: meii@fe.untar.ac.id
}

\begin{abstract}
March 2020 marks the first milestone of the COVID-19 Pandemic in Indonesia. Since then, there have been changes in interactions in the society. Year 2019 ended the pattern of interactions that characterized the pre-pandemic era. This study aims to capture the patterns of interaction between generations related to the use of cellphones in 2019 . The participants were three Chinese Belitung families, with a minimum of two generations: the baby boomer generation, and / or generation X, and / or generation $\mathrm{Y}$ and $\mathrm{Z}$. Community interaction at several coffee shops and tourist attractions, as well as the activities of adolescents at one vocational school are also the subject of observation by the researchers. The study was conducted primarily with qualitative method, and ethnographic approach. Data collection was conducted through observation, and interviews. The data were then analyzed using actor network theory. The result showed that Baby Boomers did not seem to use cellphones intensely, while Generation Y almost always fulfilled their needs through cellphones. Generation X used cellphones, however not continuously and only for fulfilling some of their needs. Among the four generations, it seems that Baby Boomers have the best social relations skills, and Generation $\mathrm{Y}$ and $\mathrm{Z}$ appears to be less concerned about their surroundings, except when schools restrict the use of cellphones. During the COVID-19 pandemic, there was a rise in the intensity of cellphone usage by children and adolescents.
\end{abstract}

Keywords: transition, interaction, community, cellphone, Belitung

\section{INTRODUCTION}

Belitung Regency and Belitung City are part of the Bangka Belitung province, the name Belitung comes from Belitung Island which is divided into two regencies, Belitung and East Belitung.

The role of the Belitung Chinese community in the life of Indonesian people as a whole is a fact that can be observed in people's lives. It is estimated that quite a number of community leaders were from Belitung Chinese families, whether known or unknown. However, there has not been sufficient published scientific study on the role of Belitung Chinese society and culture conducted by Indonesian researchers.

The part of Chinese society that shapes the culture and contributes to the life of Indonesian people is from generations, which according to the taxonomy of scientists are: (a) Silent Generation, (b) Baby Boomer Generation, (c) Generation $\mathrm{X}$ and (d) Generation $\mathrm{Y}$ is also known as the millennial generation.

The millennial generation is more often connected with technology that is in line with developing technological advances, that is information technology, compared to previous generations [1]. This interconnection affects education, leadership strategy, and how to work in an organization. The millennial generation is a generation that works hard in various fields [1]. This statement contradicts previous research, which claimed that millennials tend to be lazier.

Generational differences in symbols, heroes, rituals, and values are clear to most people. Historical events affect generations in a special way. Technological developments can also lead to differences between generations [2]. Currently, many people, especially the millennial generation, use expensive and luxurious cellphones as a form of social appearance. In addition, millennials use cellphones frequently to reduce uncomfortable feelings during social contact with other people. The reasons for excessive use of cellphones have to do with external control, material, social interaction anxiety, and the need for attention. As a result of excessive use of cellphones, individuals may experience less self-control in using cellphones, resulting in internet dependence and excessive use of credit cards [3].

How is the formation of behavior in generation $\mathrm{Y}$ or the millennial generation, especially in interaction patterns and cellphone use? What is the relation between this behavior of the $\mathrm{Y}$ generation with the previous generations? How have the patterns of interaction and cellphone use transitioned 
from the previous generation (i.e. generation $\mathrm{X}$ )? How have the patterns of interaction and use of cellphones transitioned from the generation before generation $\mathrm{X}$ (the baby boomer generation)? To answer these questions, it is necessary to discuss the characteristics of each generation.

\subsection{Baby Boomer Generation}

The Baby Boomer generation includes individuals born from 1946 to 1964 [4], [5].

The Baby Boomer generation thrived during a period of unprecedented prosperity following World War II. This generation is big on politics and social liberals who are active in radical social change including the emergence of the civil rights movement, being against the Vietnam War, women's movement, along with rapid technological changes [6]. Baby boomers are highly individualistic, competitive with a strong interest in self-fulfillment through personal growth [7]. They show level of high work ethic and involvement in work which leads to economic security and career success even though it often costs them their personal lives [8].

\subsection{Generation $X$}

Generation $\mathrm{X}$ includes individuals who were born between 1965 and 1980 [9]. The characteristics of generation $X$ are hardworking, education and achievement oriented, and family and community oriented [10].

Generation X experienced a period of economic success and hardship (early 1980 rejection and downsizing) and family problems (high divorce rates) during its formative years [8]. They learned to be individualistic, financially independent, and take risks in entrepreneurship in a workplace economy that is loyal and commitment that is not consistently reciprocal with job security [11], [12]. Generation $\mathrm{X}$ is less concerned with status and job security, but more on personal freedom and work challenges that demand a balanced work and personal life [8].

\subsection{Generation $Y$}

Millennial generation includes those born around 1981 to 2000s [13]-[15].

Generation $\mathrm{Y}$ is often referred to as the Millenial generation. Generation $\mathrm{Y}$ is a generation whose lives are greatly influenced by technological advances, especially in the use of the internet and cellphones [16].

The millennial generation is a social community that is interdependent and is involved in a wider environment due to technological advances and the ability to communicate virtually. This generation is also different from the previous generation who studied in college 10,15 or 20 years ago. Millennials have collective personalities, unique thought processes and educational levels to practice in a more traditional classroom and educational environments [17]. Important characteristics to define this generation are the lack of professional ties that are influenced by the social environment, the need for the equal feedback, a feeling of equal rights, lack of critical thinking skills, unrealistic expectations, high parental involvement, and expectations on how to achieve success and easily leave the classroom.
Millennials also want to spend less time on work and want to achieve success with less effort [17]. However, millennials hold up family values and prefer to spend time with family rather than work [18] and they focus on developing their own business rather than working as an employee for life [19]. The millennial generation, which in some literature is also called generation $\mathrm{Y}$ is also diligent in shaping and influencing a culture, training and organizing the workplace as well as looking for work through social relationships [18], [20].

\subsection{Generation $Z$}

Generation $\mathrm{Z}$ includes those who were born from 1995 to 2010 [21]. Generation $Z$ is often referred to as the postmillennial generation. Generation $\mathrm{Z}$ develops personalities and life skills in the uncertain and complex socio-economic environment. Generation $\mathrm{Z}$ is focused on career, security, safety, and privacy [22].

The use of smartphones is an important part of the life of Generation $\mathrm{Z}$ [23]. Generation $\mathrm{Z}$ seems to be a generation that is smarter, more responsible, and inclusive than the millennial generation [24]. Individuals of generation $\mathrm{Z}$ see the future of their organizational and personal lives as highly dependent on technological advances [25].

\subsection{Smartphone Use Behavior and Internet of Things (IOT)}

Currently, information and communication technology has been widely used, especially among the younger generation, such as for online games, search engines (google, yahoo, bing), social networking, email, multimedia services (including images / photos, sound, music that can be accessed through YouTube, Itunes, Kaza), and cloud computing (sky drive, iCloud). Among various information and communication technologies, internet technology and mobile technology are the two most widely used types in society, such as cellphones, smart phones, iPod, iPad, iPod Touch, and netbooks [26]. Internet technology and mobile technology in the future will be inseparable while also experiencing a rapid increase in usage in Asia Pacific [27], [28].

The development of internet technology from 2000 began when there was high demand for logistics and the internet was needed to streamline delivery routes, logistics storage, and to prevent losses in the future. Over time, until 2010 the internet has developed to become a marketing application, while serving as surveillance, security, health, transportation, food hygiene and document management to reduce costs that led to application changes. The internet continued to develop until 2020 where the function of the internet expanded to also be used for tracking people and objects everyday through geological signals, and to monitor and control something far, and being more energy efficient, while having more sophisticated software [29].

There are five levels of the attributes and functions of the internet. The first level is called smart connection level, which can be installed and played, as a barrier-free communication tool and sensor network. At the second level it is referred to as the data to information conversion level with good machine component, multidimensional data correlation, and performance degradation and prediction. 
The third level, the cyber level with the internet as the same model for components and machines, a timekeeping machine for various identification, and memory, that is grouping to equalize data search. The fourth level is known as the cognition level with the internet as integrated simulation and synthesis, remote visualization for humans, combining diagnostics and decision making. Finally, the configuration level allows the internet to configure itself for resilience, adapt to various situations, optimize itself from various disturbances [30].

Various cultural activities of the community that have developed, such as communicating, texting, clothing, building self-identity, music, daily routines, monitoring parental behavior, television programs, watching videos, browsing, meeting new acquaintances, dating, bullying, online trading and GPS causes cellphones to integrate various devices with new technologies such as digital cameras, portable digital assistant, and GPS technology. 3G and $4 \mathrm{G}$ cellphones provide private videocall services anywhere [31].

\subsection{Technology Acceptance Model dan Behavioural Intention to Use the Technology}

As with other forms of information technology, the use of information technology can be explained and predicted through several theoretical models. Two of the most widely used theoretical models are the TAM (Technology Acceptance Model) model developed by Venkatesh \& David [32] and its refined form, UTAUT (Unified Theory of Acceptance and Use of Technology) by Venkatesh, Morris \& Davis [33]. Both models are based on Theory of Reasoned Action (TRA) developed by Fishbein \& Ajzen [34].

TAM explains that the links between perceived usefulness and perceived ease of use can affect the intention to use information technology, and predict the use of information technology. TAM is based on Theory of Reasoned Action (TRA) [34] which suggests that individual behavior is imitated by the individual's intention to behave more specifically. Behavioral intention is determined by the individual's subjective attitudes and norms regarding behavioral questions. According to TRA, intensity in attitude directly regulates behavior because people generally act the way they desire.

\subsection{Social Interaction Patterns}

The pattern of human social interaction can be observed directly, through repetition of behavior. Behavior as a human response to other people can be viewed from one's attitude towards others. Attitudes are people's evaluations of aspects of the world (eg Olson \& Kendrick, cited in [35]).Baron and Branscombe explained clearly about attitudes and their effects on human behavior. A person's attitude towards others can be distinguished into positive and negative attitudes. Attitudes can influence human behavior in interacting with each other. Attitudes are formed through the process of experiential learning from the environment [35].
How attitudes can shape behavior is explained by the Theory of Planned Behavior (TPB). This theory explains and predicts how a person deals with planning attitudes and behavior in dealing with the environment. This theory was originally called Theory of Reasoned Action (TRA) and was developed in 1967 [36], which were continually revised and expanded by Fishbein and Ajzen (1975) [34]. Starting in 1980 this theory was used to study human behavior and to develop more appropriate interventions. The latest development of this theory is called the Theory of Planned Behavior (TPB).

Besides being attitude-based, Baron and Branscombe explained that the patterns of interaction between humans can also be explained in various forms of interaction, including: (a) conformity to groups; (b) empathy, caring behavior and helping others, and (c) the ability to control emotions when interacting with others [35].

\section{METHOD}

The participants were three Chinese Belitung families, with a minimum of two generations: the baby boomer generation, and / or generation $\mathrm{X}$, and / or generation $\mathrm{Y}$ and $\mathrm{Z}$. Community interaction at several coffee shops and tourist attractions, as well as the activities of adolescents at one vocational school were also the subject of observation by the researchers. The study was conducted primarily with qualitative method, and ethnographic approach. Data collection was conducted through observation, and interviews.

In an effort to obtain the results of in-depth data analysis and interpretation, this qualitative study adopted 7 basic principles developed by Klein \& Myers [37] for the data analysis. The basic principles in question are: Basic principles of hermeneutic circles, basic principles of contextualization, basic principles of interaction between the researchers and research subjects, basic principles of abstraction and generalization, basic principles of dialogical reasoning, basic principles of multiple interpretation, and basic principles of always being critical of findings.

The researchers undersood the weakness of qualitative research, which is the possibility of researcher bias. In order mitigate this weakness, apart from adopting the 7 basic principles of the hermeneutic circle, the research team conducted discussions of the interpretation of the observation and interview findings. When there are different interpretations of the results of observations and interviews, the differences are raised in the discussion to find an equivalent interpretation.

\section{FINDINGS}

There are three main findings regarding interactional patterns and cellphone usage. First, the Baby Boomers rarely use cellphones to communicate, especially with children, and they use cellphones strictly for important and emergency purposes. Second, Generation X uses cellphones, but not constantly, and only for meeting specific needs. The third finding is that Generation $\mathrm{Y}$ fulfills their needs using their cellphones.

The Baby Boomers generation prioritizes direct 
communication with family members. During family gatherings, they set a rule not to use cellphones because this generation values kinship more and avoids using cellphones. In addition, the Baby Boomers generation also prioritizes courtesy when interacting directly with others, because direct interaction is very important for building relationships with other people, and also for building business relationships. In direct interaction with other people, the Baby Boomer generation does not hesitate to interact directly with strangers and help people around them because Baby Boomers avoid using cellphones continuously

One baby boomer participant interviewed in this study was Mrs. JL, 80 years old, with her daily activities as a housewife. She rarely uses a cell phone. It is only used to call children and relatives living far away. As a baby boomer, she often advises his children and grandchildren not to use cell phones too often because it poses several harmful effects, one of them being visual impairment.

This indicates that the baby boomer generation shows empathy in their interaction pattern and concern for the health of others related to the use of cellphones as well as strong emotional control ability because they can control their emotion when using cellphones.

Generation X used cellphones, however not continuously and only for fulfilling some of their needs. Although generation $\mathrm{X}$ understands how to use cellphones better than the Baby Boomers, Generation X's interaction patterns are the same as the Baby Boomers generation, which prioritizes kinship and only uses cellphones for daily needs and emergency needs. Generation X also dislikes the continuous use of cellphones and prefers direct interaction rather than interactions via cellphones.

Generation X mostly uses cellphones for work purposes, and not for entertainment such as playing online games or watching videos.

However, generation X's ability to control emotions when using cellphones is still less than the baby boomer generation.

A generation $\mathrm{X}$ interviewed in this study is Mr. FO, 45 years old, working as a travel vehicle driver. When driving, he does not look at his cellphone constantly. If there is a phone call while driving, he does not answer the call.

Based on this, generation $X$ has the ability to control their emotions when using cellphones and can determine when to use cellphones and when to not use cellphones.

Generation Y or the millennials are active cellphone users. This generation prefers communicating with text and often shares messages or a new application with others. This generation also has a high sense of optimism and is teamoriented. This generation tends to be focused on the current situation or situation at hand.

Generation $\mathrm{Y}$ is a generation born in an era of technology that continuously develop. Individuals in this generation are known to have multi-tasking abilities, full of creative ideas, being flexible and responsive to environmental changes.

A millenial interviewed in this study was $\mathrm{IH}, 30$ years old, working as a notary. IH always holds his cellphone and seems inseparable from it. When occupied with work, he often glances at his cellphone. When not working, he tends to use his cellphone to play online games and also watch his favorite videos.

Generation $\mathrm{Z}$ likes to communicate using text accompanied by pictures. This generation prefers creating new messages and applications rather than just sharing existing messages or applications. This generation is realistic and is futureoriented in their actions.

Generation $\mathrm{Z}$ is currently studying in middle school, high school and in college.

Based on an observation on students in a vocational high school, it was evident that every student has a cellphone. They are allowed to use cellphones during their breaks. However, there were also students who used cellphones during lessons when unsupervised.

Generation $\mathrm{Z}$ tends to not pay attention to their environment when using cellphone. They are indifferent to others and have poor emotional control. If asked to stop when using their cellphone, they will become visibly unhappy and angry because they feel that their leisure time is disturbed.

Of the 4 generations, it can be seen that Baby Boomers have the best social relations skills while generations $\mathrm{Y}$ and $\mathrm{Z}$ seem to care little about their surroundings unless the school sets rules regarding the use of gadgets. Unlike the Baby Boomers and the generation $\mathrm{X}$, the interaction patterns of generations $\mathrm{Y}$ and $\mathrm{Z}$ include ignoring the surrounding environment due to the continuous use of cellphones, besides generations $\mathrm{Y}$ and $\mathrm{Z}$ preferring interactions via cellphones rather than direct interactions which leads to these generations using their cellphones frequently.

Both generations lack emotional control due to continuous use of cellphones, and mobile online games frequented by this generation leads to low emotional control. The results of this study are supported by Herring \& Thompson and Takahashi [38], [39] which also claimed that generation $\mathrm{Z}$ prefers to use information technology rather than direct interaction in communicating with others via video calls using gadgets.

During the COVID-19 pandemic, there was a rise in the intensity of cellphone usage by children and adolescents.

This increase is due to work from home and home based learning activities. These activities rely on cellphones as a medium for communication. This certainly leads to increasing cellphone usage, especially among generations $\mathrm{X}$, $\mathrm{Y}$ and $\mathrm{Z}$.

Based on several observations, the use of cellphones among generation $\mathrm{X}$ is for work. However, for generation $\mathrm{Y}$ and especially generation $Z$, the use of cellphones for playing online games and watching videos is increasing. The use of cellphones even takes place continuously while neglecting to take a break.

The interaction pattern of each generation is briefly described in table 1. 
Table 1. Interaction pattern of each generation

\begin{tabular}{|l|l|l|l|}
\hline & $\begin{array}{l}\text { Group } \\
\text { Conformity }\end{array}$ & $\begin{array}{l}\text { Empathy, } \\
\text { caring } \\
\text { behavior, } \\
\text { and } \\
\text { helping } \\
\text { others }\end{array}$ & $\begin{array}{l}\text { Emotional } \\
\text { control }\end{array}$ \\
\hline $\begin{array}{l}\text { Baby } \\
\text { Boomer }\end{array}$ & +++ & +++ & +++ \\
\hline Generation X & ++ & ++ & ++ \\
\hline $\begin{array}{l}\text { Generation } \\
\text { Y/Z }\end{array}$ & + & + & + \\
\hline
\end{tabular}

If the data above is analyzed using Actor Network Theory, it appears that in the lives of each generation, cellphones have become an important part that can be considered as an important non-human actor in the patterns of interaction between individuals. Other actors who also play a role in shaping the behavior of the Belitung people are other family members and members of other communities, both inside and outside the city of Belitung.

Through cellphones, the relationship between several generations in one family can be established. Furthermore, through cell phones, community members can conduct business or other work relationships. Cellphones are a non-human actor that is attached to each individual in each generation, and affects the interaction process between people in Belitung.

\section{CONCLUSION}

The results showed that Baby Boomers did not use cellphones often, while Generation Y almost always fulfilled their needs using them. Generation $X$ used cellphones, however not continuously and only for fulfilling some of their needs. Among the four generations, it seems that Baby Boomers have the best social relations skills, and Generation $\mathrm{Y}$ and $\mathrm{Z}$ appears to be less concerned about their surroundings, except when their schools restrict the use of cellphones.

\section{ACKNOWLEDGMENT}

This work was supported by Research Institutions and Community Engagement, Tarumanagara University, as well as research assistants: Claudia, Fenny, Hartinah, Linda, Vienchenzia, Vivien.

\section{REFERENCES}

[1] M. Au-Yong-Oliveira, R. Gonçalves, J. Martins, and F. Branco, "The social impact of technology on millennials and consequences for higher education and leadership," Telemat. Informatics, vol. 35, no. 4, pp. 954-963, 2018.
[2] M. M. G. Hofstede, G. J. Hofstede, "Culture and Organizations (Software of the Mind): Intercultural Cooperation and Its Importance for Survival," in Culture and Organizations (Software of the Mind): Intercultural Cooperation and Its Importance for Survival, 2018.

[3] Y. K. Lee, C. T. Chang, Y. Lin, and Z. H. Cheng, "The dark side of smartphone usage: Psychological traits, compulsive behavior and technostress," Comput. Human Behav., vol. 31, no. 1, pp. 373-383, 2014.

[4] J. S. G. P. Moschis, E. Lee, A. Mathur, The dark side of smartphone usage: Psychological traits, Marketplace: Buying Habits of Baby Boomers and Their Parents. Quorum Books, 2000.

[5] T. Worsley, W. C. Wang, and W. Hunter, "Baby boomers' reasons for choosing specific food shops," Int. J. Retail Distrib. Manag., vol. 39, no. 11, pp. 867-882, 2011.

[6] N. Strauss, W., \& Howe, "Generations: The History of America's Future," New York: Morrow, 1991, pp. 1584-2069.

[7] L. H. Parker, B., \& Chusmir, "A generational and sex-based view of managerial work values," Psychol. Rep., vol. 66, no. 3, pp. 947950, 1991.

[8] B. Kupperschmidt, "2000 Imp Multigenerational Employees.Pdf.” 2000.

[9] E. F. M. J. W. Gibson, G. R. A. Greenwood, "Generational Differences in the Workplace," $J$. Bus. Divers., vol. 18, no. 2, pp. 1-8, 2018.

[10] B. Miller, J. D., Laspra, "Generation X in midlife: A summary from the longitudinal study of American life," Generations, vol. 41, no. 3, pp. 27-33, 2017.

[11] K. P. De Meuse, T. J. Bergmann, and S. W. Lester, "An Investigation of the relational component of the psychological contract across time, generation, and employment status," $J$. Manag. Issues, vol. 13, no. 1, pp. 102-118, 2001.

[12] B. Tulgan, "Managing Generation X: How to bring out the best in young talent," New York: Merrit Publishing, 1995.

[13] B. News, "The original Generation X," 2014. 
[14] Creating, "CREATING A CULTURE OF INCLUSION -- LEVERAGING GENERATIONAL DIVERSITY: At-aGlance," 2010.

[15] T. Brabazon, From revolution to revelation: generation $X$, popular memory and cultural studies. Abingdon: Routledge.

[16] T. Issa and P. Isaias, "Internet factors influencing generations $\mathrm{Y}$ and $\mathrm{Z}$ in Australia and Portugal: A practical study," Inf. Process. Manag., vol. 52, no. 4, pp. 592-617, 2016.

[17] M. Monaco and M. Martin, "The Millennial Student: A New Generation of Learners," Athl. Train. Educ. J., vol. 2, no. 2, pp. 42-46, 2007.

[18] J. M. Twenge, S. M. Campbell, B. J. Hoffman, and C. E. Lance, "Generational differences in work values: Leisure and extrinsic values increasing, social and intrinsic values decreasing," J. Manage., vol. 36, no. 5, pp. 1117-1142, 2010.

[19] A. M. Broadbridge, G. A. Maxwell, and S. M. Ogden, "13230: Experiences, perceptions and expectations of retail employment for Generation y," Career Dev. Int., vol. 12, no. 6, pp. 523-544, 2007.

[20] S. Terjesen, S. Vinnicombe, and C. Freeman, "Attracting Generation Y graduates: Organisational attributes, likelihood to apply and sex differences," Career Dev. Int., vol. 12, no. 6, pp. 504-522, 2007.

[21] J. E. White, "Meet Generation Z: Understanding and Reaching the New PostChristian World.," Grand Rapids: Baker Books, 2017.

[22] K. Lanier, "5 things HR professionals need to know about Generation Z," Strateg. HR Rev., vol. 16, no. 6, pp. 288-290, 2017.

[23] M. Ozkan and B. Solmaz, "Mobile Addiction of Generation Z and its Effects on their Social Lifes," Procedia - Soc. Behav. Sci., vol. 205, no. May, pp. 92-98, 2015.

[24] M. Van Den Bergh, J. and Behrer, "How Cool Brands Stay Hot: Branding to Generations Y and Z.," London: Kogan Page Limited, 2016.

[25] V. Roblek, M. Mesko, V. Dimovski, and J. Peterlin, "Smart technologies as social innovation and complex social issues of the $\mathrm{Z}$ generation," Kybernetes, vol. 48, no. 1, pp. 91$107,2019$.

B. News, "Mobile internet use nearing 50\%," 2011

[27] M. Minges, "Is the Internet mobile? Measurements from the Asia-Pacific region," Telecomm. Policy, vol. 29, no. 2-3 SPEC.ISS., pp. 113-125, 2005.

[28] N. Report, "Turning Digital: The Asian Media Landscape.," 2012.

[29] D. Tohanean and A. Vasilescu, "Business Models and Internet of Things," Proc. Int. Conf. Bus. Excell., vol. 13, no. 1, pp. 1192-1203, 2019

[30] B. Vogel-Heuser, J. Lee, and P. Leitão, "Agents enabling cyber-physical production systems," At-Automatisierungstechnik, vol. 63, no. 10, pp. 777-789, 2015.

[31] G. Goggin, "New Technologies and the Media," London: Palgrave, 2012.

[32] V. Venkatesh and F. D. Davis, "Theoretical extension of the Technology Acceptance Model: Four longitudinal field studies," Manage. Sci., vol. 46, no. 2, pp. 186-204, 2000.

[33] V. Venkatesh, M. G. Morris, G. B. Davis, and F. D. Davis, "Quarterly," vol. 27, no. 3, pp. 425-478, 2003.

[34] I. Fishbein, M., \& Ajzen, "Belief, attitude, intention and behavior an introduction to theory and research. Reading," MA: Addison Wesley, 1975.

[35] N. R. Baron, R. A. \& Branscombe, "Social Psychology," Essex: Pearson, 2014.

[36] F. . Davis, "Perceived Usefulness, Perceived Ease of Use, and User Acceptance of Information Technology," Delle vicende dell'agricoltura Ital. Stud. $e$ note di $C$. Bertagnolli., vol. 13, no. 3, pp. 319-340, 1989.

[37] M. D. Klein, H. K., Myers, "A SET OF PRINCIPLES FOR CONDUCTING AND EVALUATING INTERPRETIVE FIELD STUDIES IN INFORMATION SYSTEMS," Context, vol. 23, no. 1, pp. 67-93, 1999. 
[38] L. Herring, J. and Thompson, "Learn the Art of Logic and Persuasionn (Collection)," New Jersey: FT Press, 2012.

[39] T. Takahashi, "Deconstructing Digital Natives: Young People, Technology and the New Literacies," New York: Routledge, 2011, pp. $67-82$. 